\title{
ANALISIS DAERAH PENANGKAPAN IKAN LAYANG (Decapterus macrosoma) DI SEKITAR SELAT KELANG
}

\author{
Fishing Ground Analysis of Layang (Decapterus Macrosoma) Around Kelang Strait \\ Djalaludin Kemhay ${ }^{1}$, Deni Sarianto ${ }^{1}$, Achmad Jais Ely ${ }^{1}$ dan Rangga Bayu Kusuma Haris ${ }^{2}$ \\ 1) Staf Pengajar Perikanan Tangkap, Politeknik Kelautan dan Perikanan Maluku \\ 2) Staf Pengajar Perikanan Tangkap, Politeknik Kelautan dan Perikanan Dumai \\ Email : kemdjalaludin@gmail.com
}

\begin{abstract}
Abstrak
Perairan Maluku merupakan daerah potensial bagi penangkapan ikan. Alat tangkap yang banyak di gunakan masyarakat selain Pole and Line adalah menggunakan alat tangkap mini purse seine. Tujuan dari penelitian ini adalah untuk menentukan komposisi jumlah dan ukuran ikan layang secara temporal dan spasial serta menentukan sebaran kandungan klorofil-a dan suhu permukaan laut di Teluk Piru. Hasil tangkapan utama mini purse seine yang beroperasi di Teluk Piru adalah layang, selar dan kembung. Layang merupakan tangkapan yang paling dominan sebanyak $41700 \mathrm{~kg}$ di ikuti oleh selar sebanyak $2550 \mathrm{~kg}$ dan kembung sebanyak $2050 \mathrm{~kg}$. Ikan layang yang tertangkap selama penelitian di dominasi dengan ukuran layak tangkap sebesar 95 persen dari total sampel yang di ambil. Ukuran ikan yang tidak layak tangkap berkisar 5\%. Kandungan klorofil-a pada lokasi penelitian memiliki kisaran 0,248 - 0.565 $\mathrm{mg} / \mathrm{m}^{3}$ dengan suhu permukaan laut (SPL) 26,115-28,658 ${ }^{\circ} \mathrm{C}$. Musim Timur tidak memberikan perubahan yang besar terhadap hasil tangkapan ikan, tetapi daerah selat memberikan pengaruh yang besar terhadap sebaran Klorofil-a dan SPL di permukaan laut.
\end{abstract}

Kata Kunci: layang, klorofil-a, suhu permukaan laut.

\begin{abstract}
Maluku waters are a potential area for fishing. The fishing gear that many people use besides Pole and Line is using a mini purse seine fishing gear. The purpose of this study is to determine the composition of the number and size of flying fish temporally and spatially and determine the distribution of chlorophyll-a content and sea surface temperature in Piru Bay. The main catches of the mini purse seine operating in Piru Bay are kites, selar and bloated. Kite is the most dominant catch as much as $41700 \mathrm{~kg}$ followed by selar as much as $2550 \mathrm{~kg}$ and bloating as much as $2050 \mathrm{~kg}$. Fly fish caught during the study were dominated by catch size of 95 percent of the total sample taken. The size of fish that are not worth catching around 5\%. The chlorophyll-a content in the study location has a range of $0.248-0.565 \mathrm{mg} / \mathrm{m3}$ with sea surface temperature (SPL) 26.115-28.665 ${ }^{\circ} \mathrm{C}$. The Eastern monsoon does not make a major change in fish catches, but the strait area has a large influence on the distribution of Chlorophyll-a and SPL at sea level.
\end{abstract}

Keywords: Flying fish, chlorophyll-a, sea surface temperature. 


\section{PENDAHULUAN}

Ikan layang (Decapterus macrosoma) merupakan salah satu komoditas perikanan unggulan bagi nelayan yang berbasis di Pangkalan Pendaratan Ikan (PPI) Leihitu, Maluku. Daerah Selat Kelang dikenal sebagai salah satu penghasil ikan laying terbesar Maluku Tengah. Ikan ini tidak hanya berperan strategis bagi sumber pendapatan nelayan setempat, tetapi juga sebagai pensuplai bahan baku industri bagi perusahan pengolahan. Keberadaan perusahaan pengolahan sangat membantu para nelayan dalam menjual hasil tangkapannya. DKP (2018) melaporkan bahwa produksi perikanan layang merupakan urutan ketiga dari seluruh komonitiperikanan laut yaitu sebesar 36527,5 ton. Nelayan yang berbasis di PPI Leihitu menangkap ikan layang tidak hanya terbatas di Selat Kelang dan Teluk Piru, tetapi juga di sekitar laut banda (Gambar 1). Hasil tangkapan nelayan di kawasan perairan tersebut didominasi oleh layang, yaitu sekitar 6,75\% (DKP 2014). Irham et al (2009) menyatakan bahwa ikan layang di perairan Maluku dapat ditemukan sepanjang tahun, mulai dari ukuran kecil (juvenil) hingga ukuran dewasa.

Suatu perairan jika didominasi oleh ikan juvenil (illegal size) mengindikasikan bahwa perairan termasuk daerah penangkapan yang tidak potensial. Ikan juvenil termasuk illegal size untuk ditangkap (Sarianto et al., 2016). Tangkapan yang didominasi oleh ikan juvenil akan membawa dampak negatif terhadap laju recruitment sumberdaya ikan dan degradasi daerah penangkapan ikan. Kondisi ini dapat menyebabkan penurunan hasil tangkapan nelayan akibat menipisnya stok ikan layang sebagaimana dilaporkan oleh (Sangaji et al., 2014). Dengan demikian, evaluasi terhadap komposisi ukuran ikan layangyang tertangkap didaerah penangkapan ikan perlu dikehatui sedini mungkin agar keberlanjutan usaha penangkapan dapat dipertahankan. Kelimpahan ikan disuatu perairan di pengaruhi oleh parameter oceanografi. Kondisi oceanografi yang sesuai dengan karakteristik biologis akan meningkatkan jumlah ikan di perairan tersebut. Seiring dengan perkembangan teknologi informasi oceanografi makin gampang di peroleh terutama dengan teknologi pengindraan jauh.

Suhu permukaan laut (SPL) dan konsentrasi klorofil-a merupakan beberapa parameter oceanografi yang penting untuk mengetahui keberadaan ikan layang dan mempermudah dalam menganalisis daerah penangkapan (Sarianto, 2018). Kondisi ini mengindikasikan bahwa SPL dan klorofil-a dapat mempengaruhi dinamika daerah penangkapan ikan. Profil SPL dan klorofil-a yang sesuai dengan karakteristik biologis yang dikehendaki oleh ikan layang dapat berpengaruh positif terhadap proses terbentuknya daerah penangkapan ikan. Tujuan dari penelitian ini adalah menentukan komposisi jumlah dan ukuran ikan layang secara temporal dan spasial serta menentukan sebaran kandungan klorofil-a dan suhu permukaan laut di Teluk Piru.

\section{METODE PENELITIAN}

\section{Waktu dan Tempat Penelitian}

Pengumpulan data tangkapan ikan layang dilakukan bulan Juni s/d Agustus 2019 di Perairan Selat Kelang, dimana nelayan yang berbasis di PPI Lehitu menangkap ikan layang. Data SPL dan klorofil-a dari (http://oceancolor.gsfc.nasa.gov) pada bulan Agustus 2019

\section{Metode Penelitian}

Metode yang digunakan dalam penelitian ini adalah metode survei, dengan mengamati 5 unit mini purse seine sebagai sampel yang menangkap ikan layang. Data yang dikumpulkan dari kegiatan penangkapan ikan meliputi waktu dan lokasi atau posisi penangkapan ikan, jumlah dan ukuran ikan yang tertangkap. Jumlah tangkapan layang dicatat pada setiap lokasi penangkapan. Sampel ikan diambil secara acak pada setiap posisi penangkapan, untuk selanjutnya diukur panjangnya (total lenght). Data klorofil-a dan suhu permukaan laut (SPL) di lokasi penelitian diperoleh dengan cara mengunduh citra SPL dan klorofil-a yang dideteksi satelit Terra/Aqua (MODIS), dan citra ini tersedia di internet (http://oceancolor.gsfc.nasa.gov.). Citra yang dipilih merupakan data harian SPL dan klorofil-a level 3 pada waktu dan tempat yang bersamaan dengan kegiatan operasi penangkpan ikan.

\section{Analisis Data \\ a. Komposisi Hasil Tangkapan}

Komposisi hasil tangkapan dianalisis untuk mengetahui produktivitas atau Catch Per Unit Effort (CPUE) secara temporal dan spasial.

Keterangan:

$$
C P U E=\frac{\mathrm{C}}{\mathrm{f}}
$$

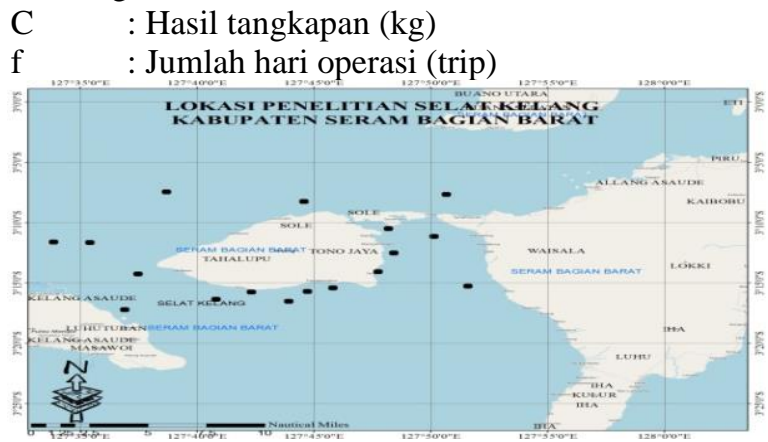

Gambar 1. Sebaran Daerah Penangkapan Ikan Layang di Selat Kelang 


\section{b. Sebaran Daerah Penangkapan}

Indikator yang digunakan dalam penentuan DPI antara lain hasil tangkapan, panjang ikan, salinitas, dan suhu permukaan laut. Evaluasi daerah penangkapan ikan dalam penelitian ini didasarkan pada dua indikator yaitu rata-rata ukuran panjang ikan yang tertangkap dan kandungan klorofil-a. Ukuran panjang ikan dilapangan akan dibandingkan dengan ukuran panjang ikan pertama kali matang gonad atau length at first maturity (Lm). Ikan layak tangkap memiliki ukuran panjang rata-rata lebih besar dari panjang pertama kali ikan matang gonad (Alamsyah and Musbir, 2014). Apabila panjang ikan yang tertangkap lebih kecil dari atau sama dengan Lm, maka daerah penangkapan ikan dikategorikan tidak potensial.

Tabel 1. Penilaian DPI melalui indikator CPUE

\begin{tabular}{llc}
\hline $\begin{array}{c}\text { Kategori Ukuran } \\
\text { Panjang }\end{array}$ & \multicolumn{1}{c}{ Kriteria } & $\begin{array}{c}\text { Kategori } \\
\text { DPI }\end{array}$ \\
\hline Besar & Panjang ikan $\geq$ & Potensial \\
& LM & \\
Kecil & Panjang ikan $<$ & Tidak \\
& LM & potensial \\
\hline Sumber : (Sarianto 2016) &
\end{tabular}

\section{c. Sebaran SPL dan Klorofil-a}

Data sebaran SPL dan klorofil-a hasil deteksi satelit Terra Aqua MODIS diolah dengan software SeaDAS 7.5 level 3 hingga didapat data dalam bentuk asciikemudian diolah dengan excel dan disajikan dalam bentuk grafik. Suhu permukaan air laut didapatkan dengan menggunakan algoritma Miami Pathfinder SST (MPFSST) (Minnett et al. 2002 dalam Sarianto, 2018) dengan rumus :

modis $\left._{s s t}=c_{1}+c_{2} * T_{31}+c_{3} * T_{3132}+c_{4} *(\sec (\theta)-1) * T_{3132}\right)$

Keterangan:

$\mathrm{T}_{31} \quad$ : brightness temperature (BT) pada band 31 (pada AVHRR kanal 4)

$T_{3132} \quad$ : pebedaan BT pada band 31-band 32 (pada AVVHRR kanal 4 dan 5)

$c_{1}, c_{2}, c_{3}, c_{3}$ : koefisien band 31 dan $32, \theta$ adalah sudut zenith satelit.

Sebaran klorofil-a didapatkan dengan menggunakan formulasi algoritma OC3M (ocean chlorophyll three-band algoritma for MODIS), dengan rumus:

Chlor_a $=10^{\left(\mathrm{a}_{0}+\mathrm{a}_{1} \times \mathrm{RR}+\mathrm{a}_{2} \times \mathrm{RR} 2+\mathrm{a}_{3} \times \mathrm{RR} 3+\mathrm{a}_{4} \times \mathrm{RR} 4\right)}$

a0 $=0.2830, \mathrm{a}_{1}=-2.753, \mathrm{a}_{2}=1.457, \mathrm{a}_{3}=0.659$ dan

$\mathrm{a}_{4}=-1.403$

yang mana :

$$
R=\log 10\left(\frac{\left.R_{r s} 403\right\rangle R_{r s} 488}{R_{r s} 551}\right)
$$

Keterangan: $\mathrm{R}_{\mathrm{rs}}$ adalah Remote Sensing Reflectance
Variabilitas atau keragaman data merupakan salah satu teknik yang digunakan untuk menjelaskan homogenitas data SPL dan klorofil-a.Variabilitas atau keragaman data dapat dihitung menggunakan rumus sebagai berikut (Sugiyono 2007dalam Sarianto, 2018):

$$
\begin{aligned}
s^{2}=\frac{\sum_{i=1}^{n}\left(x_{i}-\bar{x}\right)^{2}}{n-1} & \\
s & =\sqrt{s^{2}} \\
K v & =\frac{s}{x} .100 \%
\end{aligned}
$$

Keterangan :

$\begin{array}{lll}s^{2} & : & \text { Ragam contoh } \\ s & : & \text { Simpangan baku } \\ x_{i} & : & \text { Data ke-i } \\ x & : & \text { Rata-rata } \\ K v & : & \text { Koefisien variasi }\end{array}$

d. Hubungan Hasil Tangkapan dengan SPL dan Klorofil-a

Untuk menentukan hubungan antara klorofil-a dengan hasil tangkapan dan antara suhu permukaan laut dengan hasil tangkapan maka dilakukan analisis deskriptif dengan teknik overlay antara SPL dengan hasil tangkapan dan klorofil-a dengan hasil tangkapan. Selanjutnya data tesebut disajikan dalam bentuk peta tematik.

\section{HASIL DAN PEMBAHASAN}

\section{Produksi Layang yang didaratkan}

Jumlah total tangkapan hasil tangkapan mini purse seine yang didaratkan di PPI Leihitu pada saat penelitian adalah 42,250 ton. Tangkapan tersebut berasal dari berbagai kawasan perairan Selat Kelang dan Teluk Piru (Gambar 2). Hasil tangkapan mini purse seine didominasi oleh layang, selar, dan kembung. Hasil tangkapan terbanyak setiap kali melakukan penangkapan adalah ikan layang. Hasil tangkapan layang terjadi fluktuasi pada bulan Juni sampai Juli sedangkan memasuki bulan Agustus hasil tangkapan mengalami kenaikan yang cukup tinggi dimana sampai akhir bulan Agustus hasil tangkapan mencapai $8210 \mathrm{~kg}$. Penangkapan ikan selar dan ikan kembung tidak terlalu memperlihatkan hasil tangkapan yang banyak dimana hasil tangkapan selar pada bulan 18 juni dan 29 Agustus adalah yang tertinggi $300 \mathrm{~kg}$ dan $310 \mathrm{~kg}$. Tangkapan kembung jauh lebih sedikit dari hasil tangkapan selar dimana tangkapan terbanyak terdapat pada tanggal 18 juni dan 28 juli sebesar $400 \mathrm{~kg}$ dan $210 \mathrm{~kg}$.

Operasi penangkapan ikan layang di Selat Kelang tidak hanya dilakukan oleh nelayan yang berasal dari Leihitu, tetapi juga dilakukan oleh 
nelayan yang berasal dari Kelang, Pulau Buru, Pulau Seram. Pemanfaatan ikan layang di Selat Kelang terkadang menimbulkan konflik karena nelayan dari Leihitu dan Kelang saling mengklaim bahwa kawasan perairan tersebut merupakan daerah operasinya. Oleh karena itu, para stakeholders terkait perlu menyusun zonasi penangkapan yang lebih jelas untuk digunakan sebagai acuan dalam sharing pemanfaatan DPI di Selat tersebut.

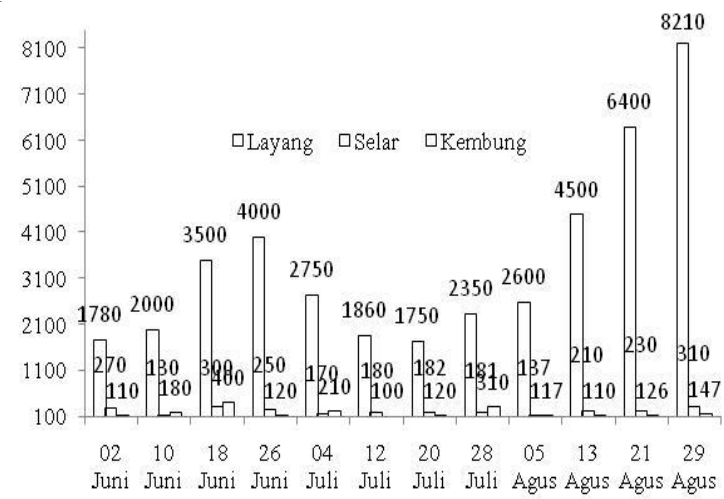

Gambar 2. Jumlah Produksi Mini Purse Saine pada Bulan Juni sampai Agustus 2019

\section{Ukuran Panjang Ikan Layang}

Ukuran ikan layang yang tertangkap selama penelitian sangat beragam mulai dari ukuran kecil hingga besar (Gambar 3). Ikan layang di kelompokan dalan 3 ukuran: kelompok pertama ikan layang berukuran kurang dari $15 \mathrm{~cm}$, kelompok kedua ikan layang ber ukuran antara 16- $20 \mathrm{~cm}$, dan kelompok ke tiga layang berukuran diatas $21-30 \mathrm{~cm}$. Ikan layang yang dominan tertangkap dalam penelitian bulan Juni - Agustus 2019 adalah kelompok ketiga, yaitu sebanyak 654 ekor dari total sampel 1000 ekor. Urutan berikutnya adalah kelompok kedua 296 ekor serta yang paling akhir adalah kelompok ketiga sebesar 50 ekor.

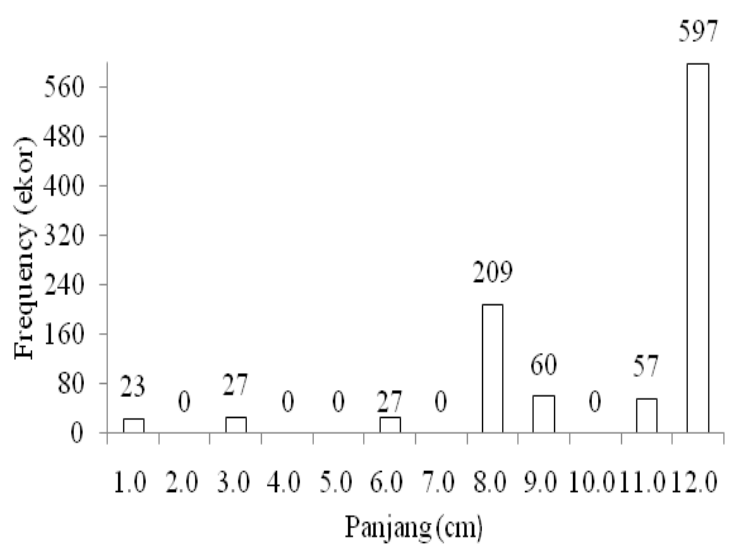

Gambar 3. Sebaran Ukuran Panjang Ikan Layang yang Tertangkap Mini Purse Seine

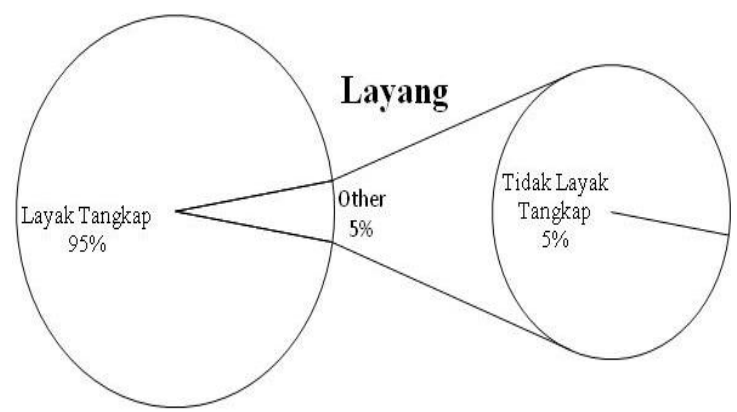

Gambar 4. Persentase Ukuran Ikan Layak tangkap dan Tidak Layak Tangkap

Hasil tangkapan yang paling dominan tertangkap dalam penelitian ini adalah layang yang terdiri atas $15 \mathrm{~cm}$ dimana ikan layang ini dikategorikan sebagai ikan layak tangkap (Gambar 4). Tangkapan layang layak tangkap mencapai 90 persen dari total sampel yang terkumpul. Sedangkan ikan layang yang tidak layak tangkap berjumlah 10 persen dari total sampel yang ada. Sarianto, at al (2016) menyatakan ukuran ikan layang layak tangkap di perairan Maluku memiliki panjang diatas $16 \mathrm{~cm}$. Menurut Ongkers et al., (2017) menyebutkan hasil tangkapan layang di Bulan Juli sampai Agustus di perairan Maluku didominasi oleh ukuran matang gonad dengan panjang $17 \mathrm{~cm}$. Ukuran rata yang didapat tidak berbeda jauh dengan ikan layang di laut jawa 15,53 cm (Widodo, 1990). Terjadinya perbedaan ukuran matang gonad pada ikan dikarenakan faktor lingkungan dan musim (Kasmi et al., 2017).

3. Klorofil-a di Selat Kelang dan Hubungannya dengan Tangkapan Layang

Kandungan klorofil-a yang terdapat pada Selat Kelang berfluktuatif setiap Minggunya (Gambar 5). Kandungan klorofil-a di perairan Selat Kelang berkisar antara $0,207-0,997 \mathrm{mg} / \mathrm{m}^{3}$, dan kandungan klorofil-a rata-rata sebesar $0,424 \mathrm{mg} / \mathrm{m}^{3}$. Kandungan klorofil-a mingguan mengalami perubahan, klorofil-a cenderung tinggi pada akhir bulan Februari serta pada tanggal 18 Juni dan 13 Agustus 2019. Kandungan klorofil-a rata-rata pada saat penelitian pada tanggal 18 Juni 2019 memiliki konsentrasi yang paling besar di Selat Kelang yaitu sebesar $0,6.63 \mathrm{mg} / \mathrm{m}^{3}$ dan konsentrasi terendah sebesar $0,248 \mathrm{mg} / \mathrm{m}^{3}$ yang terjadi pada tanggal 15 Februari dan 1 Maret 2015.

Penelitian (Haumahu, 2005) menunjukkan bahwa kelimpahan plankton di perairan Maluku berfluktuasi tergantung pada perubahan musim. Variasi konsentrasi klorofil-a memberikan pengaruh langsung maupun tidak langsung terhadap produksi ikan layang di Selat Kelang. Hubungan antara klorofil-a dengan produksi ikan layang yang didaratkan di TPI Leihitu selama bulan Juni Agustus 2019 disajikan pada Gambar 5. Secara 
keseluruhan tren fluktuasi konsentrasi klorofil-a dan produksi layang hampir sama, namun puncak peningkatan klorofil-a dan layang tidak terjadi secara bersamaan.

Keberadaan klorofil-a mempengaruhi jumlah hasil tangkapan nelayan PPI Leihitu (Gambar 5). Saat konsentrasi klorofil-a rendah pada tanggal 2 Juni 2019, hasil tangkapan ikan layang di PPI Leihitu juga menunjukkan nilai yang rendah juga. Pada tanggal 10 Juni 2019 sampai 26 Juni 2019 konsentrasi klorofil-a mengalami peningkatandan volume hasil tangkapan ikan layang juga mengalami peningkatan. Akan tetapi peningkatan klorofil-a pada tanggal 20 Juli 2019 tidak dikuti oleh peningkatan jumlah hasil tangkapan. Hal ini menunjukkan bahwa peningkatan jumlah plankton di perairan tidak selalu memberikan dampak terhadap peningkatan jumlah tangkapan secara langsung. Kondisi ini terjadi akibat adanya time lag didalam rantai makanan. Selain faktor makanan, faktor lingkungan juga sangat berpengaruh terhadap penyebaran ikan. Ikan layang umumnya menyukai perairan dengan arus yang tidak begitu kuat dan kaya akan kandungan klorofil-a (Amri et al., 2017).

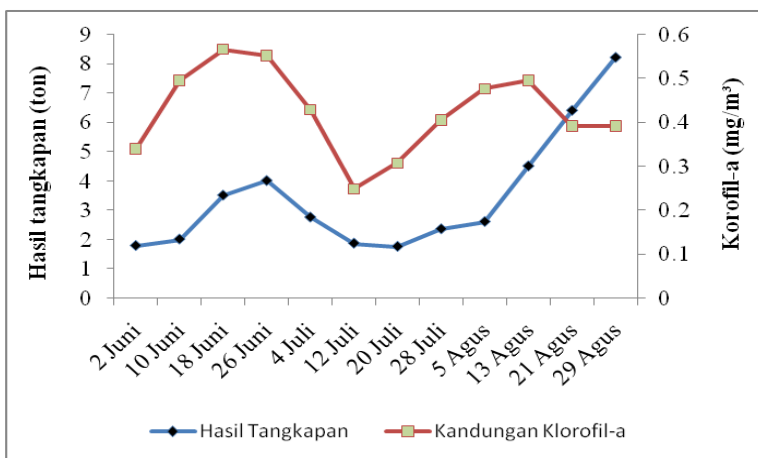

Gambar 5 Hubungan Kandungan Klorofil-a dengan Hasil Tangkapan di PPI Leihitu secara Temporal

Hubungan antara peningkatan konsentrasi klorofil-a dan produksi layang di Perairan Leihitudan Selat Kelang terkait dengan melimpahnya plankton sebagai sumber makanan ikan layang. Pada musim timur, perairan Selat Kelang danTeluk Piru lebih tenang, sehingga unsur hara ikut terangkut ke lapisan permukaan dan selanjutnya berperan penting untuk pertumbuhan plankton. Kelimpahan plankton yang rendah ini menyebabkan ikan laying kurang karena ikan ini termasuk kelompok planktonfeeder.

\section{Sebaran Suhu Permukaan Laut di Selat Kelang dan Hubungannya dengan Tangkapan layang}

Ikan layang yang didaratkan di PPI Leihitu 98\% ditangkap dengan purse seine pada pagi hari dan malam hari.SPLrata-rata di perairan Selat Kelang bulan Juni - Agustus 2019 berkisar antara 26,1$28,6^{\circ} \mathrm{C}$ (Gambar 6). Hasil penelitian ini sesuai dengan penelitian Yuliati et al. (2016) yang menyatakan bahwasuhu perairan Maluku pada musim Timur berkisar antara $26-28,5^{\circ} \mathrm{C}$. Hasil penelitian ini juga senada dengan pendapat (Habibie and Nuraini, 2014), Suhu air laut di perairan Indonesia umumnya berkisar antara $26-31,5^{\circ} \mathrm{C}$. Suhu perairan Selat Kelang terendah terjadi pada tanggal 13Agustus yaitu sebesar $26,115^{\circ} \mathrm{C}$. Kenaikan suhu yang sangat drastis terjadi pada tanggal 10 Juni, 14, dan 15 Agustus. Suhu yang rendah diperairan disebabkancurah hujan yang cukup tinggi dan penutupan awan yang tebal menyebabkan intensitas radiasi matahari sangat sedikit sehingga SPL menjadi dingin(Simbolon, 2010).

Sebaran SPL dan produksi ikan layang yang didaratkan di TPI Leihitu selama bulan Juni sampai Agustus 2019 disajikan pada Gambar 6. Pada saat tanggal 5 - 13 Agustus hasil tangkapan naik sedangkan suhu perairan menurun.Ikan layang tertangkap pada kisaran suhu antara $26,15^{\circ}-28,65^{\circ} \mathrm{C}$, dengan suhu rata-rata $27,26^{\circ} \mathrm{C}$. Hasil tangkapan tertinggi terjadi pada tanggal 26 juni, 13-29 Agustus 2019 dengan hasil tangkapan sebesar 4;4,5 ;6,40; 8,21 ton dengan suhu permukaan laut sebesar 27,8 ; 26,$15 ; 27,12 ; 27,15^{\circ} \mathrm{C}$. Hasil penelitian ini sesuai dengan penelitian Amri et al (2017), kepadatan layang tertinggi terdapat pada perairan yang memiliki suhu berkisar $27^{\circ}-28^{\circ} \mathrm{C}$. Hasil tangkapan terendah terjadi pada tanggal 2 Juni 2019 dengan suhu permukaan laut sebesar $27,4^{\circ} \mathrm{C}$. Hasil tangkapan yang rendah pada tanggal 2 Juni diduga karena telah masuk puncak terang bulan.

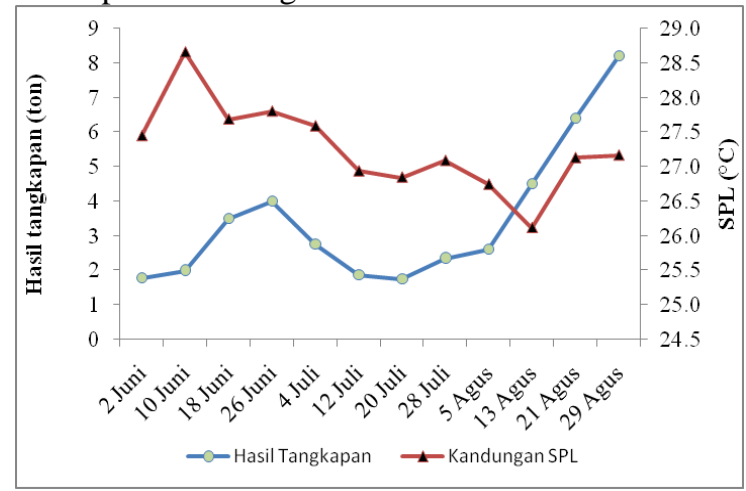

Gambar 6. Hubungan Hasil Tangkapan Layang dengan SPL Harian pada Bulan Juni Agustus 2019 secara Temporal

Menurut Simbolon (2008), menytakan bahwa pengaruh suhu perairan terhadap sebaran ikan sangat tergantung pada variabilitas suhu itu sendiri. Jika sebaran suhu perairan masih berada pada kisaran nilai yang dapat ditoleransi ikan, maka suhu perairan umumnya tidak berpengaruh secara nyata terhadap keberadaan ikan. Kondisi inilah yang diduga terjadi 
pada penelitian ini sehingga SPL tidak berpengaruh nyata terhadap hasil tangkapan ikan layang.

\section{KESIMPULAN DAN SARAN}

\section{Kesimpulan} adalah:

Kesimpulan yang diperoleh dari penelitian ini

a. Ikan Layang yang tertangkap di Selat Kelang dan Teluk Piru berada kelompok layak tangkap dimana ikan layang yang tertangkap mencapai 41,7 ton dengan ikan sampingan berupa selar dan kembung sebanyak 4,6 ton.

b. Hasil tangkapan layang pada musim timur tidak terlalu signifikan akan tetapi hasil tangkapan layang didominasi ikan ukuran layak tangkap yaitu sebesar 95 persen .

c. Kandungan klorofil-a di Perairan Selat Kelangpada bulan Juni sampai Agustus 2019 berpengaruh terhadap komposisi jumlah hasil tangkapan ikan layang

\section{Saran}

Penelitian lanjutan terkait dengan hasil tangkapan layang pada seluruh musim penangkapan perlu dilakukan agar dinamika daerah penangkapan layang dapat diamati pada musim yang berbeda;

\section{DAFTAR PUSTAKA}

Anonim. 2019. Ocean Color Web. http://www.oceancolor.gsfc.nasa.gov [diunduh: 10September 2019]

Alamsyah, R., and Musbir, F.A. (2014). Struktur Ukuran dan Ukuran Layak Tangkap Ikan Cakalang (Katsuwonus Pelamis) di Perairan Teluk Bone. Jurnal Ipteks Pemanfaatan Sumberdaya Perikanan2, 11-20.

Amri, K., Suwarso, S., and Awwaludin, A. (2017). Kondisi Hidrologis dan Kaitannya Dengan Hasil Tangkapan Ikan Malalugis (Decapferus macarellus) Di PerairanTelukTomini. Jurnal Penelitian Perikanan Indonesia. 12, 183-193.

Dinas Kelautan dan Perikanan Provinsi Maluku. 2018. Laporan Statistik Perikanan Provinsi Maluku Tahun 2018. Maluku.

Habibie, M.N., and Nuraini, T.A. (2014). Karakteristik dan Tren Perubahan Suhu Permukaan Laut di Indonesia Periode 19822009. Jurnal Meteorologi Dan Geofisika15.
Haumahu, S. (2005). Distribusi Spasial Fitoplankton di Perairan Teluk Haria Saparua, Maluku Tengah. Ilmu Kelautan: Indonesian Journal of Marine Sciences 10, 126-134.

Irham., Wisodo,H R., Haluan, J., Wiryawan, B(2009). Pengembangan Berkelanjutan Sumberdaya Ikan Layang (Decapterus spp) di Perairan Maluku Utara [Disertasi]. Sekolah Pasca Sarjana IPB. Bogor

Sangaji, J., Kusumastanto, T., and Simanjuntak, S.M. (2014). Analisis Depresiasi dan Kebijakan Pengelolaan Sumberdaya Ikan Layang di Wilayah Perairan Kota Ambon. Journal of Agriculture, Resource and Environmental Economics 1.

Sarianto, D. (2018). Analisis Daerah Penangkapan Ikan Cakalang (Katsuwonus pelamis) di Sekitar Bacan dan Obi, Halmahera Selatan. SEMAH Jurnal Pengelolaan Sumberdaya Perairan 2.

Sarianto, D. Dinamika Daerah Penangkapan Ikan, Kaitannya Dengan Aktivitas Pertambangan Nikel Kabupaten Halmahera Timur.[Thesis]. Bogor (ID): Sekolah PascaSarjana IPB.

Sarianto, D., Simbolon, D., and Wiryawan, B. (2016). Dampak Pertambangan Nikel Terhadap Daerah Penangkapan Ikan di Perairan Kabupaten Halmahera Timur. Jurnal Ilmu Pertanian Indonesia 21, 104-113.

Simbolon, D. (2008). Pendugaan daerah penangkapan ikan tongkol berdasarkan pendekatan suhu permukaan laut deteksi satelit dan hasil tangkapan di Perairan Teluk Palabuharatu. Jurnal Litbangda NTT4, 23-30.

Simbolon, D. (2010). Eksplorasi daerah penangkapan ikan cakalang melalui analisis suhu permukaan laut dan hasil tangkapan di perairan Teluk Palabuhanratu. Jurnal Mangrove Dan Pesisir $1,42-49$.

Widodo, J. (1990). Population dynamics and management of'ikan layang, scad mackerel, Decapterus spp. (Pisces: Carangidae) in the Java Sea.

Yuliati., Atmadipoera,S A., Hartanto, T H (2016). Pola Arus Serta Variabilitas Suhu Permukaan Laut Dan Klorofil-A Di Sekitar Perairan Yamdena, Maluku Tenggara Barat [Thesis]. Sekolah PascaSarjana IPB. Bogor 